\title{
Safe Food Practices among the Regimental Food Handlers of Selected Military Unit
}

\author{
Hoque $\mathrm{MA}^{1}$, Rahman $\mathrm{N}^{2}$, Mahmud $\mathrm{MK}^{3}$ \\ DOI: https://doi.org/10.3329/jafmc.v16i1.53844
}

\begin{abstract}
Introduction: Food safety is a key public health concern. Food handlers play an important role in ensuring food safety throughout the chain of preparation, storage and serving.
\end{abstract}

Aim: To assess the food safety practice level among the food handlers of selected unit messes in Dhaka Cantonment.

Methods: This descriptive cross sectional study was conducted among the food handlers of selected unit messes in Dhaka Cantonment from January 2013 to December 2013. A total of 133 food handlers were selected following convenient sampling technique. Data were collected by face to face interview using a predesigned semi-structured questionnaire and check list. All completed questionnaires were validated manually and data were analyzed with Statistical Package for the Social Sciences (SPSS) verson 15.0 by using descriptive and inferential statistics.

Results: In this study, the food handlers had a mean age of 32.9 years; all were male and Muslim. Regarding educational qualification, majority (42.9\%) were between class $\mathrm{VI}$ to $\mathrm{X}$ and $80.5 \%$ were married. The mean monthly income of the participants was taka $17,115.8$ and $53.4 \%$ belonged to nuclear family. Majority (65.4\%) of the participants were cook and $39.8 \%$ had family members between $4-5$ persons. It was found that out of all food handlers $12 \%$ had good, $78.9 \%$ had average and $9.0 \%$ had poor food safety practice status. Descriptive statistics revealed that occupation, education and marital status played a major role for food safety practice level.

Conclusion: Efforts need to be taken to improve the awareness among the food handlers. Safety practices and further studies are recommended on determinants of non-compliance to safety practices by the food handlers.

Key-words: Safe food parctices, Food Handlers, Food Safety, Public health concern.

\section{Introduction}

Food safety is a fundamental human right. According to World Health Organization (WHO), "Food safety is the assurance that food when consumed in the usual manner does not cause harm to human health and well being"1. According to Griffith 'food safety' synonymous with food hygiene, embraces anything in the processing, preparation or handling of food to ensure it is safe? ${ }^{2}$.
Food safety is a scientific discipline describing handling, preparation, and storage of food in ways that prevent food borne illness. According to WHO, five key principles of food hygiene should be maintaind to prevent food from contaminating with pathogens spreading from people, pets, and pests; separate raw and cooked food to prevent contaminating cooked foods; cook foods for appropriate length of time and temperature to kill pathogens; store food at the proper temperature and use safe water and cooked materials ${ }^{3}$.

Consumption of unsafe food is a serious threat to public health in Bangladesh for last couple of decades. A survey conducted by the Institute of Nutrition and Food Science, Dhaka University, in early 1980s had revealed that inadequate diets and intake of adulterated foods are responsible for the malnutrition of $60 \%$ of the people of Bangladesh ${ }^{4}$. Especially children are more vulnerable than adults as unsafe food is a major cause of child mortality ${ }^{5}$. Universally it is accepted that, unsafe food is an important factor of malnutrition, which causes various types of serious illnesses including diarrhoea along with other permanent consequences for the human body ${ }^{6}$.

\section{Materials and Methods}

This cross sectional study was conducted during the period of 01 January 2013 to 31 December 2013, among the food handlers (cook, maschalchi, table boy, mess waiter) of different messes in Dhaka Cantonment. Sample size was 133 and sampling technique was convenient sampling. A predesigned semi-structured interviewer administered questionnaire and check list were used as research instrument. Before collecting data, informed written consent from the participants were taken by the researcher. The participants were given full assurance on ethical point of view that under no circumstances, findings of the interview would be disclosed to any unauthorized person.

\section{Results}

Among the food handlers majority i.e. 55(41.4\%) were in the age group 26-35 years followed by $36(27.1 \%)$ were within $36-45$ years with mean age 32.9 years. Most of the participants (107, 80.5\%) were married while 26(19.5\%) participants were unmarried. Among the participants, majority i.e. 57(42.9\%) food handlers were educated between class VI to X level, while 52(39.1\%) were in SSC level. Majority i.e. 70(52.6\%) participants had monthly family income between taka 10001-20000, 35(26.3\%) less than taka

1. Maj Muhammad Anwarul Hoque, MBBS, MPH, General Staff Officer-2 (Training), Armed Forces Medical College (AFMC), Dhaka (E-mail: hoque101287.ah@gmail.com) 2. Dr Nazmin Rahman, MBBS, FCPS, Assistant Professor of Surgery, Shaheed Monsur Ali Medical College, Uttara Model Town, Uttara, Dhaka 3. Maj Mohammad Khalid Mahmud, MBBS, MPH, Genral Practitioner, Kuwait Armed Foreces. 
10000 and 9(6.8\%) had monthly income taka 30001-40000 (Table-I). All the food handlers (100\%) had the practice of hand washing before cooking food, cleaning raw food materials before cooking and cooking food at right temperature followed by 100(75.2\%) had habit of hand washing after touching body during food preparation, 74(55.6\%) used gown during cooking and 29(21.8\%) used cap during food preparation (Table-II). Safety practices during food storage and food serving has been shown in Table-III \& IV respectively. Among the participants 100(82.7\%) used soap water, 23(17.3\%) had the practice of using only water for washing hand (Figure-1), 127(95.5\%) participants had clean trimmed nails and $129(97 \%)$ had haircut (Table-V). On the basis of selected questions and giving weightage to each answer on food safety practice status among the food handlers, categorization was done as good, average and poor practice and found that out of all food handlers 16(12\%) had good, 105(78.9\%) had average and 12(9.0\%) had poor food safety practice status (Figure-2).

Table-l: Socio-demographic status of food handlers ( $n=133)$

\begin{tabular}{|c|c|c|c|}
\hline \multicolumn{2}{|c|}{ Variable } & Participants & $\%$ \\
\hline \multirow{5}{*}{$\begin{array}{c}\text { Age } \\
\text { (in years) }\end{array}$} & $16-25$ & 27 & 20.3 \\
\hline & $26-35$ & 55 & 41.4 \\
\hline & $36-45$ & 36 & 27.1 \\
\hline & $46-57$ & 15 & 11.3 \\
\hline & \multicolumn{3}{|c|}{ Mean $(+S D) 32( \pm 9.32)$} \\
\hline \multirow{2}{*}{$\begin{array}{c}\text { Marital } \\
\text { Status }\end{array}$} & Married & 107 & 80.5 \\
\hline & Unmarried & 26 & 19.5 \\
\hline \multirow{6}{*}{$\begin{array}{l}\text { Educational } \\
\text { Status }\end{array}$} & Illiterate & 3 & 2.3 \\
\hline & Class I-V & 14 & 10.5 \\
\hline & Class VI-X & 57 & 42.9 \\
\hline & S.S.C & 52 & 39.1 \\
\hline & H.S.C & 4 & 3.0 \\
\hline & Graduate & 3 & 2.3 \\
\hline \multirow{5}{*}{$\begin{array}{l}\text { Monthly } \\
\text { Family } \\
\text { Income } \\
\text { (Taka) }\end{array}$} & $5000-10000$ & 35 & 26.3 \\
\hline & $10001-20000$ & 70 & 52.6 \\
\hline & $20001-30000$ & 12 & 9.0 \\
\hline & $30001-40000$ & 7 & 5.3 \\
\hline & $40001-50000$ & 9 & 6.8 \\
\hline
\end{tabular}

Table-II: Food safety practice during food preparation $(\mathrm{n}=133)$

\begin{tabular}{|l|c|c|}
\hline Practice & Yes (\%) & No (\%) \\
\hline Hand-wash before food preparation & $133(100)$ & 0 \\
\hline $\begin{array}{l}\text { Hand wash after touching body } \\
\text { during food preparation }\end{array}$ & $100(75.2)$ & $33(24.8)$ \\
\hline Clean row food materials before cooking & $133(100)$ & 0 \\
\hline Use of gloves during cooking food & 0 & $133(100)$ \\
\hline Use of gown during cooking food & $74(55.6)$ & $59(44.4)$ \\
\hline Use of cap during cooking & $29(21.8)$ & $104(78.2)$ \\
\hline Cooking food at right temperature & $133(100)$ & 0 \\
\hline
\end{tabular}

Table-III: Distribution of respondents by food safety practice during storage of cooked food ( $n=133$ )

\begin{tabular}{|l|c|c|}
\hline Practice & Yes (\%) & No (\%) \\
\hline $\begin{array}{l}\text { Use of clean utensils/ dishes for } \\
\text { storage of cooked food }\end{array}$ & $133(100)$ & 0 \\
\hline Store cooked food at Refrigerator & $55(41.4)$ & $78(58.6)$ \\
\hline Store cooked food at Cupboard & $78(58.6)$ & $55(41.4)$ \\
\hline Maintain temperature of Refrigerator & $127(95.5)$ & $6(4.5)$ \\
\hline
\end{tabular}

Table-IV: Food safety practice during food serving $(n=133)$

\begin{tabular}{|l|c|c|}
\hline Practice & Yes (\%) & No (\%) \\
\hline Hand wash before serving food & $133(100)$ & 0 \\
\hline Use of protective net before serving food & $112(84.2)$ & $21(15.8)$ \\
\hline Use of clean utensils for serving food & $133(100)$ & 0 \\
\hline Use of gloves during serving food & $4(3.0)$ & $129(97.0)$ \\
\hline Use of gown during serving food & $33(24.8)$ & $100(75.2)$ \\
\hline Use of cap during serving food & $13(9.8)$ & $120(90.2)$ \\
\hline Use of face mask during food handling & 0 & $133(100)$ \\
\hline
\end{tabular}

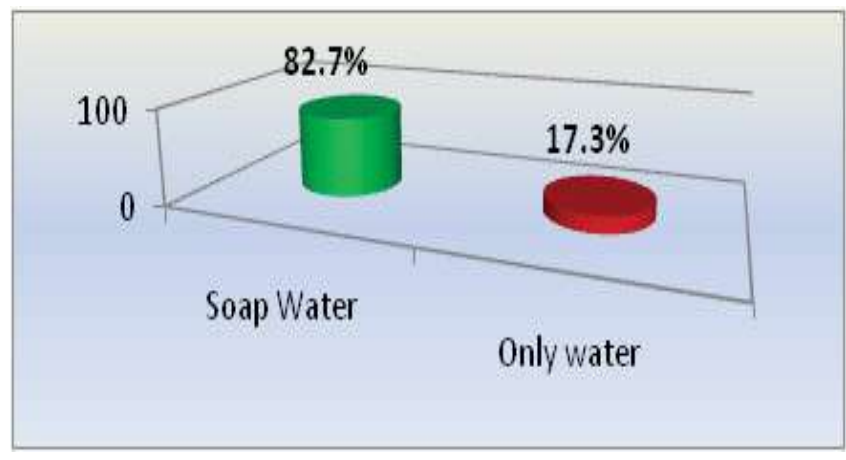

Figure-1: Material used by food handlers for hand washing $(n=133)$

Table-V: Condition of nail and hair of the participants $(n=133)$

\begin{tabular}{|l|c|c|c|}
\hline Condition & Yes (\%) & No (\%) & Total (\%) \\
\hline Trimmed nails & $127(95.5)$ & $6(4.5)$ & $133(100)$ \\
\hline Hair cut & $129(97)$ & $4(3)$ & $133(100)$ \\
\hline
\end{tabular}

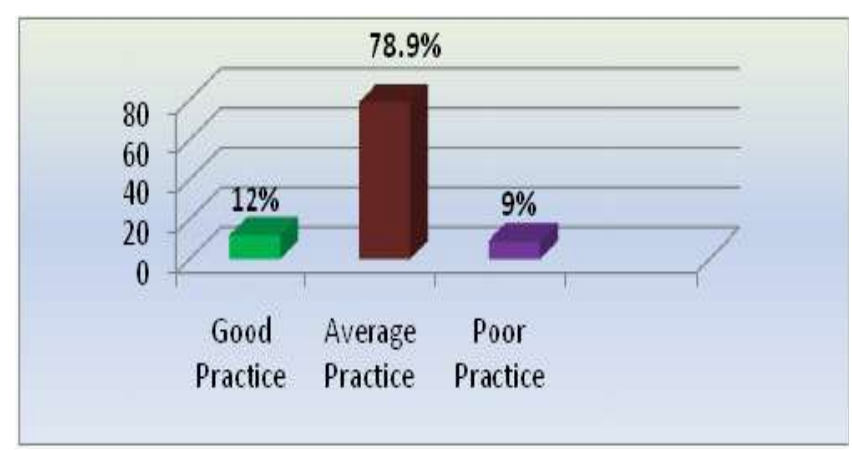

Figure-2: Food safety practice level of food handlers $(n=133)$

\section{Discussion}

Food is a potential source of infection and is liable to contamination by microorganism, at any point during its journey from the producer to consumer. Still food borne diseases are leading medical challenges of the twenty- first century and also appearing as a public health problem in developing countries like India, Sri Lanka and Bangladesh. The aim of the study was to assess the food safety practice level of the food handlers of selected unit messes in Dhaka Cantonment.

The mean age of the food handlers was 32.94 years and maximum i.e. 55(41.4\%) were in the age group 26-35 years and lowest $15(9.8 \%)$ were within $46-57$ years. The study finding is consistent

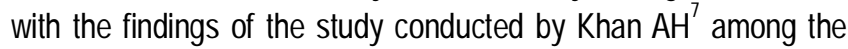
food handlers on knowledge and personal hygiene practice in hotels at district town Gazipur where he found age group of the 
majority food handlers (68.6\%) were in the range of 25-35 years. Another study conducted by Mizanur $\mathrm{R}$ et $\mathrm{al}^{8}$ found mean age of respondents was 30.9 years which also similar with present study.

Regarding educational qualification, the study showed that out of all the participants, majority i.e. 57(42.9\%) food handlers were educated between class VI to X level, while $3(2.3 \%)$ were graduate level qualified and only $3(2.3 \%)$ were illiterate. The study finding is consistent with findings of study conducted by Thidarat $\mathrm{C}$ et al ${ }^{9}$ in Thailand where he found $52.2 \%$ was primary graduate and $6.5 \%$ did not attend school. The illiteracy rate differs from the studies conducted by Chowdhury $\mathrm{FA}^{10}$ and Mudey $\mathrm{AB}$ et $\mathrm{al}^{11}$ among the food handlers where they found illiteracy rate was $49.8 \%$ and $63.13 \%$ respectively.

The mean monthly income of food handlers was 17115.8 taka. The study revealed that majority i.e. 70 (52.6\%) food handlers had their monthly family income between taka 10001-20000. This study findings does not correlate with the findings of the studies conducted by Dhar $\mathrm{S}^{12}$ and $\mathrm{Khan} \mathrm{AH}^{7}$, they found monthly income of majority respondent were ranged taka 1000-2000 and taka 1000-1500 respectively. Monthly income of the food handlers in this study was high probably due to all the food handlers were in service.

Health is the paramount importance in Bangladesh army. Practice on maintenance of health can be achieved by increasing food safety practice level. The study showed that $100 \%$ of the food handlers had habit of washing hand before preparing and serving food which does not correlate with the findings of the study conducted by SK Roy ${ }^{13}$ regarding household food safety and hygiene knowledge, attitudes and practices (KAP) in Bangladesh. The study revealed practice of hand washing immediately before preparing food was among $48.5 \%$ of the respondents, hand washing immediately before serving food was $66.5 \%$ of the respondents. The higher level of practice in Military may be due to higher educational qualifications of food handlers serving in Army.

It was found from the study that $100 \%$ of the food handlers did not use hand gloves during handling food which coincide with the study conducted by Chowdhury FA ${ }^{10}$ where it was found that none of the respondents had the habit of using hand gloves before handling food. The study findings is dissimilar to the findings of the study conducted by Siow ON et a ${ }^{14}$. Regarding food safety for the assessment of Knowledge, attitudes and practices (KAP) among food handlers at residential colleges and canteen in Malaysia found that $52.3 \%$ used gloves during handling food. It was also found from the present study that $24.8 \%$ of the participants had practice of using gown and $9.8 \%$ had practice of using cap during preparing food which is dissimilar to the study findings conducted by Thidarat $C$ et $a^{9}$ where it was found $69.2 \%$ used gown and $84.6 \%$ food handlers had practice of using cap during handling food.

This study depicted that $75.2 \%$ of the respondents had the practice of hand washing after touching body and this finding does not coincide with the study conducted by Chowdhury FA ${ }^{10}$ where $49.3 \%$ of respondents had the habit of washing hands after touching body.

It was also evident from the study that among the participants $82.7 \%$ had the practice of using soap water and $17.3 \%$ had the practice of using only water for washing hand which disagree with the study of SK Roy ${ }^{13}$ where he found $14.3 \%$ used soap water and $48.7 \%$ used only water. This may be due to higher educational qualifications of food handlers serving in Army and better management and control. This study revealed that $95.5 \%$ food handlers had trimmed nail. This finding was close to the findings of the study conducted by Mudey Ab et al ${ }^{11}$ in India where they found $89.1 \%$ had clean nails.

It was evident from the present study that, out of 133 food handlers $12 \%$ food handlers had good food safety practice level, $78.9 \%$ had average practice level and $2.9 \%$ had poor food safety practice level. The finding is consistent with finding of the study conducted by Thidarat Cet $\mathrm{a}^{9}$ in Thailand, where he showedamong the food handlers $15.2 \%$ had a good practice. The study finding differs from study conducted by Chowdhury FA $^{10}$ who found $71.2 \%$ food handlers of Dhaka University hostel had poor hygiene practice habit and $28.8 \%$ had good hygiene practice habit. The food safety practice status of army food handlers is better probably due to good educational background, awareness and disciplined life.

\section{Conclusion}

Food safety is an utmost concern in the twenty-first century and a major public health issue for the consumers. This study depicted that food safety practice level was average among majority of the food handlers. Good food safety practice was found better among educated and married person than less educated and unmarried. Majority of the food handlers did not use hand gloves, gown, cap and face mask during preparation. Efforts need to be taken to improve the awareness among the food handlers to adopt safe food practices.

\section{References}

1. World Health Organization (WHO). Global strategy for food safety. Geneva: WHO, 2002.

2. Griffith CJ. Food Safety: Where from and where to? British Food Journal 2006; 108(1):6-15.

3. WHO. Five keys to safer food. Available from: http://www.who.int , foodsafety > publications > consumer. Accessed on 2013-10-12.

4. Ali QM. Some aspects of consumer protection in Bangladesh, The Dhaka University Studies 1984; Part-C:111-19.

5. The State of the World's Children 2008: Child Survival, United Nations International Children's Emergency Fund; 2007, December. Available from: http://www.unicef.org/sowc08/docs/sowc08. Accessed on 2013-10-12.

6. Motarjemi Y, Kaferstein F, Moy G. Contaminated Weaning Food: A 
Major Risk Factor for Diarrhoea and Associated Malnutrition, Bulletin of the World Health Organization, 1993:79.

7. Khan $\mathrm{AH}$. Knowledge and personal hygiene practice of food handlers in hotelsat district town Gazipur, JOPSOM 2004; 15(1):15-8.

8. Rahman MM, Arif MT, Bakar K et al. Food safety knowledge, attitude and hygiene practices among the street food vendors in Northern Kuching City, Sarawak. Borneo Science 2012; 31:1-103.

9. Thidarat C, Suwat S, Duangjai M. Food safety knowledge, attitude and practice of food handlers and microbiological and chemical food quality assessment of food for making merit for monks, Thailand: Asia Journal of Public Health 2011; 2(1):31-2.

10. Chowdhury FA. Personal hygiene practice among the food handlers of Dhaka University hostels. JOPSOM 2009; 25(2):18-21.
11. Mudey AB, Kesharwani N, Mudey GA. Health status and personal hygiene among food handlers working at food establishment around a rural teaching hospital in wardha district of Maharashtra, India. Global journal of Health Science 2010; 2(2):198-206.

12. Dhar S. Personal hygiene practice and distribution of intestinal parasites among the restaurants of Mohakhali area, Dhaka. JOPSOM, 2000; 7(1):6-9.

13. SK Roy. Survey of household food safety and hygiene practice, knowledge and beliefs in Bangladesh 2011. Available from http://www.bd food safety/Roy_ICDDRB\%20. Accessed on 2013-10-12.

14. Siow ON and Norrakiah AS. Assessment of Knowledge, Attitudes and practices (KAP) among food handlers at residential colleges and canteen regarding food Safety. Sains Malaysiana J 2011; 40(4):403-10. 